Article

\title{
Risk Level Evaluation on Construction Project Lifecycle Using Fuzzy Comprehensive Evaluation and TOPSIS
}

\author{
Tsegay Gebrehiwet*(D) and Hanbin Luo \\ Institute of Construction Management, School of Civil Engineering and Mechanics, Huazhong University of \\ Science and Technology, Wuhan 1037, China; luohbcem@hust.edu.cn \\ * Correspondence: tseggt77@hust.edu.cn; Tel.: +86-131-250-96204
}

Received: 17 November 2018; Accepted: 17 December 2018; Published: 24 December 2018

\begin{abstract}
A risk is a predominant problem in the developing countries construction projects. Although numerous studies have been concerned on risk, there is a limited study on a mechanism to identify the typical risks and effects level. This paper presents an approach for evaluating the risks in case of schedule delays at the various lifecycles of construction projects. The methodology applied is an integrated model of the technique for order preference by similarity to ideal solution (TOPSIS) and fuzzy comprehensive evaluation (FCE). In this study, common criteria, sub-criteria, and attributes are constructed to make a decision concerning the influence level of risk of delay at the construction project lifecycle. The results showed that the construction stage (44\%) is highly influenced, the second highly influenced stage is post construction (37\%), and the least risked stage is pre-construction (35\%). The construction projects in Ethiopia have faced an average delay risk of $38 \%$ at a high and very high-risk level. This work is expected to serve as a tool to assist managers in the management and control of schedule delays to mitigate their risks.
\end{abstract}

Keywords: FCE; Construction project; Evaluation of schedule delay risk; TOPSIS

\section{Introduction}

Construction projects have a complex nature owing to the site work difficulty, labour change for every site, adverse weather effect, and the higher exposure to error [1]. Consequently, numerous types of risks are occurred in different phases of projects and have an impact on time overrun, cost overrun, quality, and safety [2]. Schedule delay risk has many effects such as increased cost, late completion, disruption, third-party claims, loss of productivity and quality, disputes, and termination of contracts [3]. Therefore, controlling risks in a construction project has been a fundamental part of management in construction projects for decades [4].

A schedule is the main concern for construction projects, because of it influenced by several risks, such as environmental condition, equipment efficiency, productivity, material delivery, and soil types [5]. These factors are caused to delay and cost overruns that often jeopardize safety and quality performance [6]. For example, $13 \%$ of the Australian construction projects have faced $40 \%$ time overrun [7]. In the United Arab Emirates (UAE), the construction projects encountered 50\% schedule delay [8]. In Malaysia, the government projects faced approximately $20 \%$ of delay [9]. Construction projects in Saudi Arabia experienced 70\% time overrun, among 56\% of consultants and $76 \%$ of contractors experienced $10-30 \%$ of delay, which causes to approximately $50 \%$ of cost overruns [10]. In Ethiopia, 40-60\% of the construction projects occurred delay [11]. The studies indicate that the risk of schedule delay in developed and developing countries is critical and requires further investigation. 
Risk of Schedule delay has a major negative effect on participating parties and projects [12]. Schedule delay often occurs because of many reasons attributable to owners or contractors. The significant contribution of owners often related to issues such as the settlement of claims, slow decision-making, early planning and design, change in the scope, schedule delay in payment, and excessive bureaucracy. Conversely, the contribution of contractors includes cash flow problems, difficulty in obtaining permits, and ineffective planning and scheduling [13]. The main groups of schedule delay factors were classified as owner, contractor, design, consultant, labour, equipment, material, external, and project-related [14]. The other important schedule delay factors mentioned are a slow decision by authorities, lack of funding, errors in work, improper planning, and lack of need identification [15].

Different scholars have conducted different studies on risk. However, the problem of risk is still prevalent. Moreover, the problem requires a pioneering decision-making mechanism to evaluate risk [16]. The evaluation of risk helps to quantify the risks level to mitigate their effects. Therefore, managers need to emphasize on a decision-making mechanism for schedule risk evaluation [6]. The evaluation mechanism should consider the risk throughout the construction lifecycle. Evaluation of risks on construction projects improves quality, safety, reduces cost, and increases the satisfaction of stakeholders.

The objective of this study is to evaluate the delay risk level at the construction lifecycle and comparing the lifecycle to each other. The study evaluates the risk impact level for criteria and sub-criteria based on the different attributes. Finally, the study proposes a method for delay risk evaluation using an integrated decision model of the Technique for Order Preference by Similarity to Ideal Solution (TOPSIS) and fuzzy comprehensive evaluation (FCE).

\section{Literature Review}

Improper risk management is found to be the main cause for the time overrun, cost overrun, and the problem of quality and safety [4]. Risk management is a crucial and important part of the decision-making process for construction projects to reduce risk [17]. Risk management has been investigated from a different viewpoint among certain countries because of the fact that the risk effect varies in different instances [18]. Various researchers have studied the causes and effects of risk for decades to identify the risk factors. Most of the previous studies focused more on the identification of general risk factors and effects than identifying the typical level of impact at the different construction lifecycles.

The studies in different countries identified different risk problems using different methods. However, the method has a certain limitation. One of the most vital methods is the application of the integrated methods of a relative importance index and fuzzy analytical hierarchy process, have been used to reduce risk [19]. This assessment method has limitations in imprecision and involves subjective judgment [14]. The integration of interpretive structural modelling with fuzzy logic has an important role in risk assessment. The model used a computer program to form a relationship between factors in a system [18]. However, this method overlooked the weight of the relationship between factors that makes difficult to use in a complex system [20]. Bayesian belief network developed to quantify the probability of delay risk in construction project considering the cause-effect relations among factors [21,22]. In addition, System Dynamic (SD) plays a respective advantage for schedule delay risk effects investigation based on the causal loop diagrams considering the simulation-based scheduling [23]. Although the System Dynamics and Bayesian Belief Network are important for risk assessment, the methods had restrictions on the structural relationship. Different studies may have different structures of relations and assumptions between factors, this makes confined the models because it may vary from one expert to another $[22,24]$. The structural equation modelling considers the complex nature of factors and used a causal relationships modelling technique for analyzing the relationship between the factors [25]. However, the method has a certain curb that the risk paths in the design and the dynamic behaviour of the risk factors were not considered [18]. The different 
methods may have different contribution with certain limitations, especially for risk assessment [26]. In addition, the different studies in the different methods have still lacked a systematic approach to consider the complex and dynamic nature of construction projects risk for better understanding and effective risk management [27]. The aforementioned methods contributed for better assessment of schedule delay risk but the studies still have some confined. First, the evaluation of risk impact level throughout the construction lifecycle has limitations. Second, the assessment methods have been identifying the relations and ranking of factors, but most of the studies were confined to evaluate the level of impact of factors on different construction activities.

To fill this gap, this study aims to propose a hybrid model for delay risk assessment in construction projects with the aid of FCE and TOPSIS. The hybrid model helps managers to have appropriate decision-making mechanism to minimize schedule risk impact. The integrated model of FCE and TOPSIS is an important mechanism to detect typical delay risk impact in construction projects, which is beyond the identification of factors and relationships between factors.

\section{Research Methodology}

FCE and TOPSIS are essential for selecting and ranking a set of factors with usually incommensurate and independent attributes [28]. FCE and TOPSIS are supporting tools for decision-making in a finite number of alternatives [29]. The integrated model plays the respective advantage of flexibility in order to achieve a better result and make the right decision by identifying the typical level delay risk on construction activities. The layout of the evaluation mechanism of schedule delay risk using integrated models of FCE and TOPSIS is described in Figure 1.

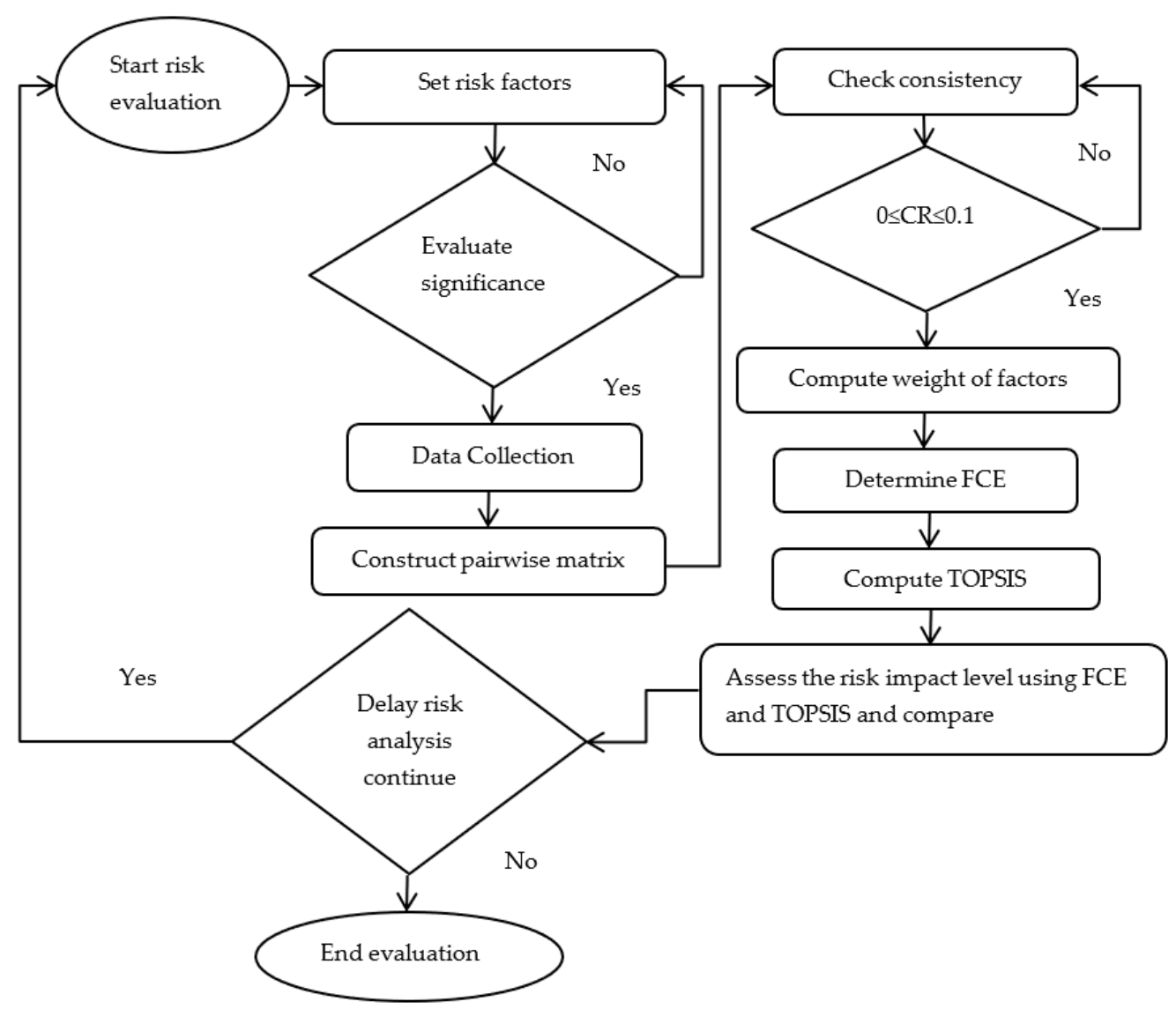

Figure 1. The layout of delay risk evaluation using integrated models of fuzzy comprehensive evaluation (FCE) and the technique for order preference by similarity to ideal solution (TOPSIS). 


\subsection{Set Significant Delay Risk Factors}

Set significant delay risk factors: it involves the identification and classification of delay risk factors and their consequences [19]. The procedure of selecting factors expressed as, based on the extensive literature review, a questionnaire for pilot study was developed, then the pilot study was assessed in fifteen different projects and participant were interviewed and responded to the questionnaire. Next based on the literature review and pilot study final questionnaire was developed. Finally, the developed questionnaire was validated to confirm clarity, completeness, and applicability in the case study.

In this study, the construction project lifecycle considers the three basic stages of pre-construction stage, construction stage, and post-construction stage according to the pilot to fit for the empirical assessment. The risk factors listed in Table 1 were selected based on the impact that directly or indirectly associated with the three-construction lifecycle. However, the influence level of risk is completely different among the lifecycles, which is essential for decision-making in risk. The final questionnaire was consisted of four criteria, eight sub-criteria, and fifty-two attributes, as summarized in Table 1. Then based on this questionnaire data were collected.

Table 1. Schedule delay risk factors evaluation indexing system and reference.

\begin{tabular}{|c|c|c|c|}
\hline Criteria Related & Sub-Criteria Related & Attribute Related & Reference \\
\hline \multirow{17}{*}{ (A) Responsibility } & \multirow{7}{*}{ A1 Client } & $\begin{array}{l}\text { A11 Lack of on-time payments } \\
\text { and finance }\end{array}$ & {$[4,19,30,31]$} \\
\hline & & A12 Client interference & {$[4,31,32]$} \\
\hline & & $\begin{array}{l}\text { A13 Leisureliness in } \\
\text { decision-making }\end{array}$ & {$[15,19]$} \\
\hline & & $\begin{array}{l}\text { A14 Late at delivery of site for } \\
\text { design and construction }\end{array}$ & {$[4,17,30]$} \\
\hline & & A15 Inadequate feasibility study & {$[4,19,31]$} \\
\hline & & $\begin{array}{l}\text { A16 Poor coordination and } \\
\text { communication with other }\end{array}$ & {$[4,19,31]$} \\
\hline & & $\begin{array}{l}\text { A21 Problems related to } \\
\text { subcontractor }\end{array}$ & {$[4,19,31]$} \\
\hline & \multirow{4}{*}{ A2 Contractor } & $\begin{array}{l}\text { A22 Poor site performance and } \\
\text { management }\end{array}$ & {$[15,33]$} \\
\hline & & $\begin{array}{l}\text { A23 Ineffective scheduling and } \\
\text { planning }\end{array}$ & {$[4,19,30,32]$} \\
\hline & & $\begin{array}{l}\text { A24 Improper construction } \\
\text { methods }\end{array}$ & {$[19,22,33]$} \\
\hline & & $\begin{array}{l}\text { A25 Poor coordination and } \\
\text { communication with other }\end{array}$ & {$[4,30,31]$} \\
\hline & \multirow{6}{*}{ A3 Consultant } & $\begin{array}{l}\text { A26 Inadequate experience of the } \\
\text { contractor }\end{array}$ & {$[19,22,25]$} \\
\hline & & $\begin{array}{l}\text { A27 Rework for unsatisfactory } \\
\text { work }\end{array}$ & {$[17,19,22]$} \\
\hline & & $\begin{array}{l}\text { A31 Inadequate consultant } \\
\text { experience }\end{array}$ & {$[15,19]$} \\
\hline & & $\begin{array}{l}\text { A32 Late in receiving and } \\
\text { approving of work }\end{array}$ & {$[4,19,22,30]$} \\
\hline & & $\begin{array}{l}\text { A33 Late in performing inspection } \\
\text { and testing and poor supervision }\end{array}$ & [34] \\
\hline & & $\begin{array}{l}\text { A34 Poor coordination and } \\
\text { communication with other }\end{array}$ & [19] \\
\hline
\end{tabular}


Table 1. Cont

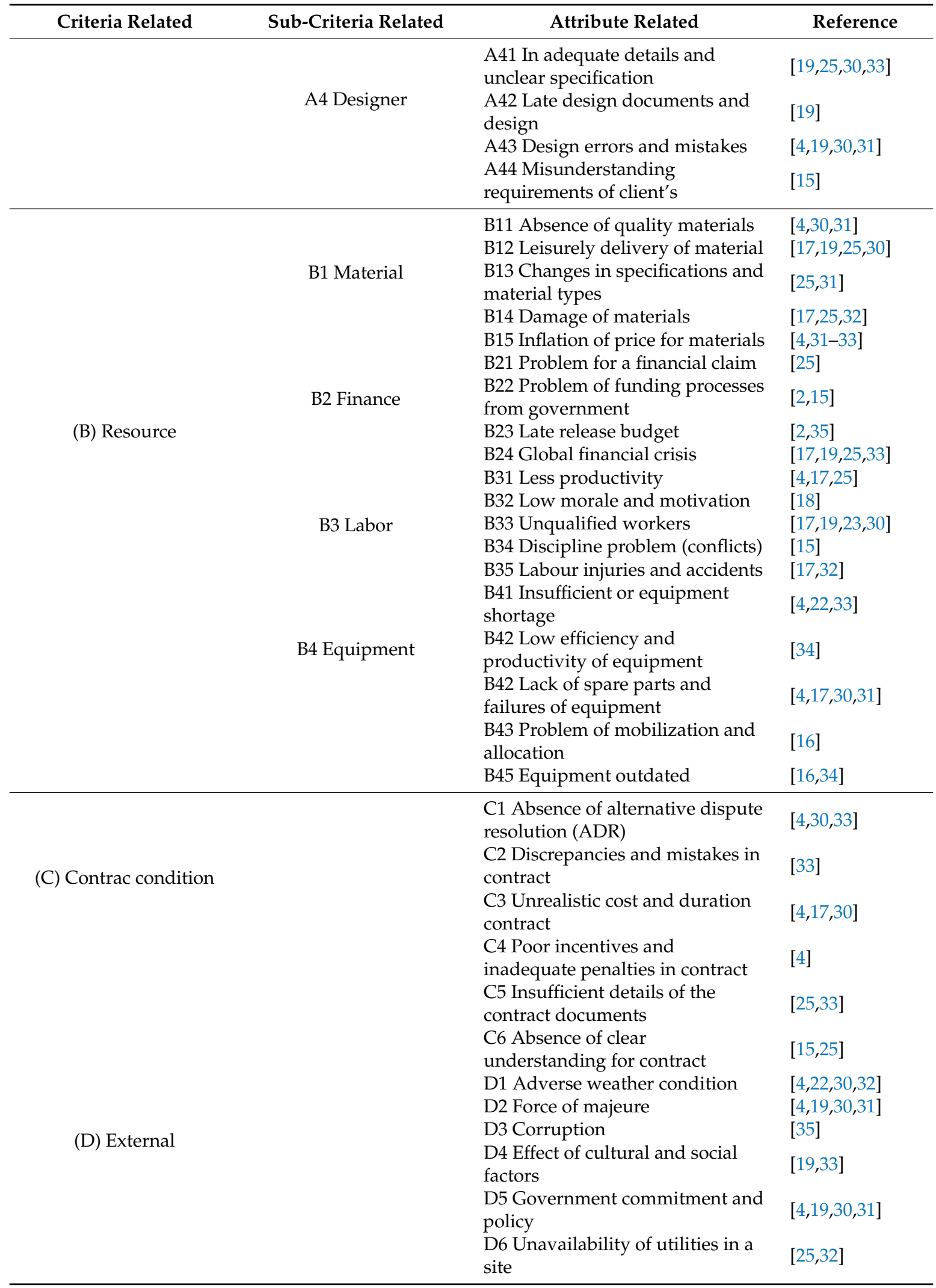




\subsection{Fuzzy Comprehensive Evaluation (FCE)}

FCE model is used to obtain reliable results in evaluating alternatives widely in an uncertain environment [35]. The FCE approach has strong evaluation abilities that lead to appropriate decision-making. The FCE generates the weight of factors and priorities factors based on expert judgment [36]. FCE determines the risk of criteria and sub-criteria of delay factors on the construction project lifecycle. To get priorities in an organized way, the FCE technique requires to decompose the decision through the following steps, based on the different studies aforementioned.

Firstly, set criteria, sub-criteria, and attributes. This step was segmented the complex problem of delay risk factors into a structured hierarchy of three levels, which are level one (criteria), level two (sub-criteria), and level three (attributes), as shown in Table 1.

Secondly, develop a pairwise comparison matrix. This matrix was constructed using the rate of scale that denotes how much one element dominates over another with respect to a given attribute. The scale value measures the degree of relative importance in a pairwise comparison matrix using linguistic variables for delay risk factors, as described in Table 2.

Table 2. The Linguistic Variables for Schedule Delay Risk Factor.

\begin{tabular}{cc}
\hline Linguistic Terms & Fuzzy Number \\
\hline Very small risk level & 1 \\
Small risk level & 3 \\
Medium risk level & 5 \\
High risk level & 7 \\
Very high risk level & 9 \\
\hline
\end{tabular}

The matrix for pairwise comparison was developed based on the judgment of respondents, as described in the matrix (1):

$$
A=\left[\begin{array}{cccc}
1 & \frac{w_{1}}{w_{2}} & \ldots & \frac{w_{1}}{w_{n}} \\
\frac{w_{2}}{w_{1}} & 1 & \ldots & \frac{w_{2}}{w_{n}} \\
\vdots & \vdots & \ddots & \vdots \\
\frac{w_{n}}{w_{1}} & \frac{w_{n}}{w_{2}} & \ldots & 1
\end{array}\right]=\left[\begin{array}{cccc}
a_{11} & a_{12} & \ldots & a_{1 n} \\
a_{21} & a_{22} & \ldots & a_{2 n} \\
\vdots & \vdots & \ddots & \vdots \\
a_{n 1} & a_{n 2} & \ldots & a_{n n}
\end{array}\right]
$$

where $A$ is the matrix with $a_{i j}$ element of the pairwise matrix in $i$ column and $j$ row and the rated weight of factors $W=\left(w_{1}, w_{2}, \ldots, w_{n}\right)$, where $(i, j=1,2, \ldots, n)$ and $n$ is the number of factors.

Thirdly, estimate normalized weight. It computed from the pairwise matrix using the arithmetic mean. The normalized weight computed by Equation (2):

$$
w_{i}=\frac{\bar{w}_{i}}{\sum_{i=1}^{n} \bar{w}_{i}} \text { but } \bar{w}_{i}=\sum_{j=1}^{n} a_{i j}(i=1,2, \ldots, n) \text { and }(j=1,2,3, \ldots, n) .
$$

where $w_{i}$ is normalized weight from the cumulative weight $\bar{w}=\left(\bar{w}_{1}, \bar{w}_{2}, \ldots, \bar{w}_{n}\right)$.

Determining consistency ratio aids to identify consistency of decision. First, compute random indexing (RI) and consistency index (CI) then determine the consistency ratio (CR). Finally, if CR is greater than or equal to zero and less than or equal to 0.1 , the judgment is consistent [37]. The relations for the checking consistency can be expressed as Equations (3):

$$
C R=\frac{C I}{R I} \quad \text { but } C I=\frac{\lambda_{\max }-n}{n-1} \quad \text { Where; } \quad \lambda_{\max }=\sum_{i}^{n} a_{i j} \times w_{i} .
$$

Finally, compute multi-comprehensive evaluation. In a multi-comprehensive evaluation, the first step is to establish a grade factor and element set. According to the delay risk factors in Table 1 , the main element set is $U=\{A, B, C, D\}$, which represents responsibility, resource, contract condition, 
and external related factors, respectively. The five grade factors determined by $V=\left\{\begin{array}{llll}v_{1} & v_{2} & v_{3} & v_{4} \\ v_{5}\end{array}\right\}$, which represents very small risk level (1), small risk level (2), medium risk level (3), high-risk level (4), and very high-risk level (5), respectively. The second step, establish a single fuzzy matrix. The single fuzzy matrix uses the respondent's rate to evaluate the risk level of attributes. The single fuzzy matrix computed using Equation (4):

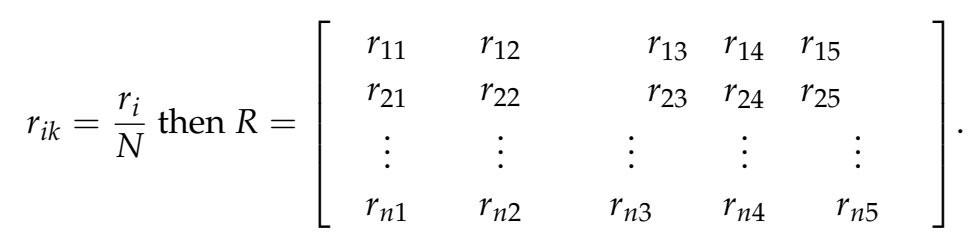

where $n$ is attributes or element set, grade factor $k=\{1,2,3,4,5\}$, the rate of respondents for grade factor $r_{i}$, the total population of respondents $N$ and single fuzzy matrix $R$.

Lastly, evaluate the comprehensive and multi comprehensive. Comprehensive evaluation compiles a single fuzzy matrix of attributes with a normalized weight of sub-criteria from the pairwise matrix to priorities influence of sub-criteria. This can be expressed using Equation (5):

$$
B_{i}=W_{i} \times R_{i}=\left[\begin{array}{c}
W_{1} \\
W_{2} \\
\cdots \\
W_{n}
\end{array}\right] \times\left[\begin{array}{ccccc}
r_{11} & r_{12} & r_{13} & r_{14} & r_{15} \\
r_{21} & r_{22} & r_{23} & r_{24} & r_{25} \\
\vdots & \vdots & \vdots & \vdots & \vdots \\
r_{n 1} & r_{n 2} & r_{n 3} & r_{n 4} & r_{n 5}
\end{array}\right]=\left[\begin{array}{llllll}
b_{i 1} & b_{i 2} & b_{i 3} & b_{i 4} & b_{i 5}
\end{array}\right] .
$$

where normalized weight of sub-criteria $W_{i}$, single fuzzy matrix $R_{i}$, and $B_{i}$ is prioritized result of sub-criteria, namely $\left[\begin{array}{lllll}b_{i 1} & b_{i 2} & b_{i 3} & b_{i 4} & b_{i 5}\end{array}\right]$.

The multi-comprehensive evaluation used to priorities the influence of criteria on alternatives. It can be computed based on Equation (6):

$$
B_{i}=W_{i} \times R_{i}=\left[\begin{array}{c}
W_{1} \\
W_{2} \\
\ldots \\
W_{n}
\end{array}\right] \times\left[\begin{array}{ccccc}
b_{11} & b_{12} & b_{13} & b_{14} & b_{15} \\
b_{21} & b_{22} & b_{23} & b_{24} & b_{25} \\
\vdots & \vdots & \vdots & \vdots & \vdots \\
b_{n 1} & b_{n 2} & b_{n 3} & b_{n 4} & b_{n 5}
\end{array}\right]=\left[\begin{array}{llllll}
b_{i 1} & b_{i 2} & b_{i 3} & b_{i 4} & b_{i 5}
\end{array}\right] .
$$

where $B_{i}$ is prioritized result of criteria, $R_{i}$ is a matrix of prioritized result from Equation (5) and $W_{i}$ is a normalized weight of criteria from the pairwise matrix

\subsection{Technique For Order Preference by Similarity to Ideal Solution (TOPSIS)}

TOPSIS is important to reasonable and rational decision-making under uncertainty, subjectivity, ambiguity, and biases [29]. TOPSIS suggests both the best and worst alternatives. The best alternative has the short distance from the positive ideal solution and the farthest distance from the negative ideal solution and vice versa [28].

In this study, precise scores of alternatives were determined by formulating a decision matrix from the linguistic variables and then forming a normalized decision matrix. Multiplying the normalized decision matrix with the normalized weight of fuzzy comprehensive evaluation has a result of weighted normalized decision matrix of attributes. Based on the weighted normalized decision matrix, the negative and positive ideal solutions, Euclidean distance, and closeness coefficient were computed. Comparing the closeness coefficient, the typical delay risk on construction project lifecycle was detected. The procedure for implementing TOPSIS presented as: 
Firstly, compute normalized decision matrix. This matrix is important because each factor has a different rated value and this rate values should convert into a single unit to enable direct comparison. The normalized decision matrix computed using Equation (7):

$$
r_{i j}=\frac{a_{i j}}{\sqrt{\sum_{i=1}^{n} a_{i j}^{2}}}, j=1,2,3, \ldots, n J, i=1,2,3, \ldots, n
$$

where $r_{i j}$ is normalized decision matrix, $a_{i j}$ is rated value of $i^{\text {th }}$ factor and $j^{\text {th }}$ alternative and $n$ is the total number of alternatives in the construction lifecycle.

Secondly, estimate the weighted normalized decision matrix. In this phase, the normalized weight from the pairwise matrix of fuzzy comprehensive evaluation multiplied with the normalized decision matrix. The weighted normalized decision matrix $v_{i j}$ calculated based on expression as (8):

$$
v_{i j}=w_{i} \times r_{i j}, j=1,2,3, \ldots, n J, i=1,2,3, \ldots, n .
$$

where $w_{i}$ is the normalized weight of $i^{\text {th }}$ factors and $r_{i j}$ is normalized decision matrix.

Thirdly, identify the negative ideal solution (NIS) and positive ideal solution (PIS). The other important thing in TOPSIS is to identify the positive ideal solution and negative ideal solution. These can be determined from weighted normalized decision matrix using Equations (9) and (10):

$$
\begin{gathered}
A^{*}=\left\{v_{1}^{*}, v_{2}^{*}, v_{3}^{*}, \ldots, v_{n}^{*}\right\} \text { maximum values, where } v_{i}^{*}\left\{\max \left(v_{i j}\right) \text { if } j \in J\right\} \\
A^{-}=\left\{v_{1}^{-}, v_{2}^{-}, v_{3}^{-}, \ldots, v_{n}^{-}\right\} \text {maximum values, where } v_{i}^{-}\left\{\min \left(v_{i j}\right) \text { if } j \in J\right\} .
\end{gathered}
$$

where negative ideal solution (NIS) and positive ideal solution (PIS) denoted by $A^{-}$and $A^{*}$, respectively.

Fourthly, determine the Euclidean distance of alternative. The Euclidean distance from the positive ideal solution (PIS) is represented by $d_{i}^{*}$ and the Euclidean distance from the negative ideal solution (NIS) is represented by $d_{i}^{-}$can be determined by Equations (11) and (12):

$$
\begin{aligned}
& d_{i}^{*}=\sqrt{\sum_{j=1}^{n}\left(v_{i j}-v_{j}^{*}\right)^{2}}, j=1,2,3, \ldots, J \\
& d_{i}^{-}=\sqrt{\sum_{j=1}^{n}\left(v_{i j}-v_{j}^{-}\right)^{2}}, j=1,2,3, \ldots, J .
\end{aligned}
$$

Finally, estimate closeness coefficient (CC). The risk level of delay determines based on closeness coefficient (CC) that deems to measure the influence level of the construction project lifecycle. The closeness coefficient (CC) expressed by Equation (13):

$$
C C_{i}=\frac{d_{i}^{-}}{d_{i}^{*}+d_{i}^{-}}, i=1,2,3, \ldots J
$$

The closeness coefficient $\left(C C_{i}\right)$ ideal solution estimates one and the closeness coefficient $\left(C C_{i}\right)$ non-ideal solution estimates zero. Therefore, the risk level of schedule delay risk on the construction project lifecycle estimates based on the value of closeness coefficient $\left(C C_{i}\right)$ ideal solution.

\section{Descriptive Case Study}

The study demonstrated through an empirical analysis in the construction projects in Ethiopia. To gather data, participants were nominated based on the purposive sampling based on their experience in the different parts of the country. The participants were experienced and they serve as clients, 
contractors, consultants, managers, engineers, designers, surveyors, and other concerned positions. To minimize the subjectivity data were collected in discussion form, from 77 different groups in the participating construction projects and each group consists of at least five experts. For the questionnaire survey, the five-point Likert scale was employed, where each point corresponded to very small level risk (1), small level risk (2), medium level risk (3), high-level risk (4), and very high-level risk (5).

Based on the pairwise matrix the normalized weight of factors are computed, this used as a weight for comprehensive and multi-comprehensive evaluation in FCE and normalized weight for TOPSIS. The product of the normalized weight with a single fuzzy matrix can give the risk impact level of sub-criteria. The impact level of sub-criteria multiplied with the weight of criteria will give risk impact level of criteria. Then, the risk level of criteria multiplied with weight will give the level of risk for the construction lifecycle, as described from Formula 3 to 6 . Whereas for TOPSIS, from the normalized weight of attributes and the normalized decision matrix, the weighted normalized decision matrix can be determined so based on the weighted normalized decision matrix the negative ideal solution (NIS), positive ideal solution (PIS), and Euclidian distance is estimated, then, finally, the closeness coefficient (CC) can be computed, as shown in formula 7 to 13 .

The comprehensive evaluation of the sub-criteria such as client, contractor, consultant, and designer represented by $\{\mathrm{A} 1, \mathrm{~A} 2, \mathrm{~A} 3, \mathrm{~A} 4\}$, respectively, under responsibility related criteria and the evaluation of sub-criteria, finance, material, labour, and equipment represented by $\{B 1, B 2, B 3, B 4\}$ respectively under resource related criteria, computed in Table 3.

Table 3. Comprehensive Evaluation of Sub-Criteria Risk on Construction Process.

\begin{tabular}{|c|c|c|c|c|c|c|c|c|c|c|c|c|c|c|c|}
\hline Sub-Criteria & \multicolumn{5}{|c|}{ Pre-Construction } & \multicolumn{5}{|c|}{ Construction } & \multicolumn{5}{|c|}{ Post-Construction } \\
\hline A1 & 0.11 & 0.24 & 0.31 & 0.21 & 0.13 & 0.09 & 0.24 & 0.30 & 0.26 & 0.11 & 0.09 & 0.21 & 0.35 & 0.17 & 0.18 \\
\hline A3 & 0.10 & 0.28 & 0.29 & 0.19 & 0.14 & 0.09 & 0.23 & 0.24 & 0.27 & 0.17 & 0.14 & 0.30 & 0.30 & 0.15 & 0.11 \\
\hline A4 & 0.09 & 0.22 & 0.27 & 0.20 & 0.22 & 0.07 & 0.24 & 0.25 & 0.22 & 0.22 & 0.14 & 0.27 & 0.28 & 0.21 & 0.10 \\
\hline B3 & 0.13 & 0.25 & 0.27 & 0.19 & 0.16 & 0.10 & 0.22 & 0.29 & 0.24 & 0.15 & 0.09 & 0.31 & 0.30 & 0.17 & 0.13 \\
\hline B4 & 0.17 & 0.26 & 0.29 & 0.18 & 0.10 & 0.08 & 0.21 & 0.27 & 0.25 & 0.19 & 0.08 & 0.22 & 0.25 & 0.20 & 0.25 \\
\hline
\end{tabular}

The multi-comprehensive evaluation results of delay risk on alternatives based on the criteria of $\{A, B, C, D\}$ that represent responsibility, resource, contract condition, and external related, described in Table 4.

Table 4. Multi-Comprehensive Evaluation of Criteria Risk on Construction Process.

\begin{tabular}{cccccccccccccccccc}
\hline \multirow{2}{*}{ Criteria } & \multicolumn{4}{c}{ Pre-Construction } & \multicolumn{4}{c}{ Construction } & \multicolumn{4}{c}{ Post-Construction } \\
\cline { 2 - 6 } & $\mathbf{1}$ & $\mathbf{2}$ & $\mathbf{3}$ & $\mathbf{4}$ & $\mathbf{5}$ & $\mathbf{1}$ & $\mathbf{2}$ & $\mathbf{3}$ & $\mathbf{4}$ & $\mathbf{5}$ & $\mathbf{1}$ & $\mathbf{2}$ & $\mathbf{3}$ & $\mathbf{4}$ & $\mathbf{5}$ \\
\hline A & 0.12 & 0.26 & 0.28 & 0.20 & 0.14 & 0.09 & 0.23 & 0.26 & 0.27 & 0.15 & 0.13 & 0.24 & 0.28 & 0.21 & 0.14 \\
B & 0.11 & 0.23 & 0.30 & 0.19 & 0.17 & 0.08 & 0.21 & 0.28 & 0.24 & 0.19 & 0.09 & 0.23 & 0.32 & 0.20 & 0.16 \\
C & 0.10 & 0.32 & 0.28 & 0.18 & 0.12 & 0.09 & 0.26 & 0.26 & 0.23 & 0.16 & 0.09 & 0.30 & 0.30 & 0.18 & 0.13 \\
D & 0.10 & 0.20 & 0.28 & 0.18 & 0.24 & 0.07 & 0.15 & 0.23 & 0.27 & 0.28 & 0.08 & 0.22 & 0.25 & 0.20 & 0.25 \\
\hline
\end{tabular}

\subsection{Evaluation of Schedule Delay Risk on Pre-Construction Stage}

The pre-construction stage has the least risk alternative with $35 \%$ of a high and very high-risk level of schedule delay as described in Table 5. The most influential criteria responsibility related is embraced by the substantial sub-criteria sequenced as designer, client, consultant, and contractor related (Tables 3 and 4). The second important criteria external related include influential factors such as corruption and unavailability of utilities at a site (Table 4). The third critical criteria resource related has momentous sub-criteria ranked as material, finance, labour, and equipment related (Tables 3 and 4). 
The least one is a contract condition related that has top contributing attributes of unrealistic cost and duration in the contract and insufficient details of the contract documents (Table 4).

\subsection{Evaluation of Schedule Delay Risk on Construction Stage}

The construction stage has the highest risk, which exposes $44 \%$ of the high and very high-risk level of schedule delay as denoted in Table 5. In the construction stage, the most influential criterion is responsibility related, with dominant sub-criteria sequenced as consultant, designer, contractor, and client related (Tables 3 and 4). The second influential criterion is resource that has important sub-criteria ranked as finance, construction material, labour, and equipment related (Tables 3 and 4). The third contract condition, which considerate influential attributes of unrealistic cost and duration in contract, and poor incentives and inadequate penalties in contract (Table 4). The external related is least one, counting the most contributing factors of corruption and unavailability of utilities at a site (Table 4).

\subsection{Evaluation of Schedule Delay Risk on Post-Construction Stage}

The second influenced by risk is the post-construction stage that covered $37 \%$ of the high and very high-risk level of schedule delay (Table 5). In this stage, the most persuasive criterion is responsibility related, with the extensive risk of sub-criteria sequenced as consultant, designer, contractor, and client related (Tables 3 and 4). The second influential criteria external related include the dominant attributes of corruption and unavailability of utilities at a site (Table 4). Contract condition is the third noticeable criterion, with top contributing attributes of unrealistic cost and duration in contract, and poor incentives and inadequate penalties in contract (Table 4). The least contributing criteria resource related, containing influential sub-criteria ranked as finance, construction material, equipment, and labour (Tables 3 and 4).

\subsection{The Schedule Delay Risk Comparison at Each Construction Lifecycle}

From multi-comprehensive evaluation matrix result of Table 5, the construction stage (44\%) is high-risk, the second high-risk stage is post construction $(37 \%)$, and the least risk stage is pre-construction (35\%).

Table 5. Risk of Schedule Delay on Construction Process.

\begin{tabular}{cccccc}
\hline Alternatives & $\mathbf{1}$ & $\mathbf{2}$ & $\mathbf{3}$ & $\mathbf{4}$ & $\mathbf{5}$ \\
\hline Pre-construction & 0.11 & 0.25 & 0.29 & 0.19 & 0.16 \\
Construction & 0.08 & 0.22 & 0.26 & 0.25 & 0.19 \\
Post-construction & 0.10 & 0.25 & 0.28 & 0.20 & 0.17 \\
Average schedule delay risk of Ethiopia construction projects & 0.10 & 0.24 & 0.28 & 0.21 & 0.17 \\
\hline
\end{tabular}

From the weighted normalized decision matrix, negative ideal solution, positive ideal solution, and Euclidean distance (Table 6) then the closeness coefficients (CC) is computed in Table 7. The higher value of closeness coefficient for a specific alternative denotes higher risk influence. 
Table 6. Weighted Normalized Decision Matrix, positive ideal solution (PIS), negative ideal solution (NIS), and Euclidian Distance of Alternatives.

\begin{tabular}{|c|c|c|c|c|c|}
\hline Factors & Pre-Construction & Construction & Post-Construction & $\operatorname{PIS}\left(A^{*}\right)$ & $\operatorname{NIS}\left(\mathrm{A}^{-}\right)$ \\
\hline A11 & 0.120 & 0.168 & 0.120 & 0.168 & 0.120 \\
\hline A12 & 0.149 & 0.106 & 0.064 & 0.149 & 0.064 \\
\hline A13 & 0.062 & 0.062 & 0.021 & 0.062 & 0.021 \\
\hline A14 & 0.162 & 0.116 & 0.116 & 0.162 & 0.116 \\
\hline A15 & 0.168 & 0.056 & 0.056 & 0.168 & 0.056 \\
\hline A16 & 0.056 & 0.019 & 0.019 & 0.056 & 0.019 \\
\hline A21 & 0.041 & 0.095 & 0.123 & 0.123 & 0.041 \\
\hline $\mathrm{A} 22$ & 0.109 & 0.140 & 0.140 & 0.140 & 0.109 \\
\hline A23 & 0.147 & 0.082 & 0.115 & 0.147 & 0.082 \\
\hline A24 & 0.043 & 0.099 & 0.043 & 0.099 & 0.043 \\
\hline A25 & 0.014 & 0.041 & 0.040 & 0.041 & 0.014 \\
\hline A26 & 0.042 & 0.099 & 0.099 & 0.099 & 0.042 \\
\hline A27 & 0.012 & 0.035 & 0.081 & 0.081 & 0.012 \\
\hline A31 & 0.122 & 0.073 & 0.073 & 0.122 & 0.073 \\
\hline A32 & 0.171 & 0.171 & 0.220 & 0.220 & 0.171 \\
\hline A33 & 0.121 & 0.121 & 0.170 & 0.170 & 0.121 \\
\hline A34 & 0.122 & 0.171 & 0.171 & 0.171 & 0.122 \\
\hline A41 & 0.197 & 0.154 & 0.110 & 0.197 & 0.110 \\
\hline A42 & 0.206 & 0.206 & 0.160 & 0.206 & 0.160 \\
\hline A43 & 0.197 & 0.154 & 0.110 & 0.197 & 0.110 \\
\hline A44 & 0.070 & 0.070 & 0.070 & 0.070 & 0.070 \\
\hline B11 & 0.136 & 0.136 & 0.136 & 0.136 & 0.136 \\
\hline B12 & 0.136 & 0.136 & 0.136 & 0.136 & 0.136 \\
\hline B13 & 0.104 & 0.104 & 0.074 & 0.104 & 0.074 \\
\hline B14 & 0.099 & 0.043 & 0.071 & 0.099 & 0.043 \\
\hline B15 & 0.136 & 0.136 & 0.136 & 0.136 & 0.136 \\
\hline B21 & 0.142 & 0.142 & 0.142 & 0.142 & 0.142 \\
\hline B22 & 0.137 & 0.098 & 0.176 & 0.176 & 0.098 \\
\hline B23 & 0.140 & 0.180 & 0.180 & 0.180 & 0.140 \\
\hline B24 & 0.099 & 0.139 & 0.139 & 0.139 & 0.099 \\
\hline B31 & 0.174 & 0.104 & 0.104 & 0.174 & 0.104 \\
\hline B32 & 0.102 & 0.170 & 0.102 & 0.170 & 0.102 \\
\hline B33 & 0.245 & 0.245 & 0.175 & 0.245 & 0.175 \\
\hline B34 & 0.036 & 0.036 & 0.036 & 0.036 & 0.036 \\
\hline B35 & 0.030 & 0.089 & 0.030 & 0.089 & 0.030 \\
\hline B41 & 0.181 & 0.325 & 0.253 & 0.325 & 0.181 \\
\hline B42 & 0.097 & 0.289 & 0.161 & 0.289 & 0.097 \\
\hline B43 & 0.040 & 0.040 & 0.040 & 0.040 & 0.040 \\
\hline B44 & 0.040 & 0.040 & 0.040 & 0.040 & 0.040 \\
\hline B45 & 0.040 & 0.040 & 0.040 & 0.040 & 0.040 \\
\hline $\mathrm{C} 1$ & 0.018 & 0.018 & 0.088 & 0.088 & 0.018 \\
\hline $\mathrm{C} 2$ & 0.025 & 0.02 & 0.025 & 0.025 & 0.025 \\
\hline C3 & 0.123 & 0.172 & 0.172 & 0.172 & 0.123 \\
\hline $\mathrm{C} 4$ & 0.069 & 0.115 & 0.161 & 0.161 & 0.069 \\
\hline C5 & 0.126 & 0.126 & 0.126 & 0.126 & 0.126 \\
\hline C6 & 0.125 & 0.075 & 0.075 & 0.125 & 0.075 \\
\hline D1 & 0.052 & 0.017 & 0.017 & 0.052 & 0.017 \\
\hline D2 & 0.055 & 0.018 & 0.055 & 0.055 & 0.018 \\
\hline D3 & 0.182 & 0.182 & 0.182 & 0.182 & 0.182 \\
\hline D4 & 0.020 & 0.020 & 0.020 & 0.020 & 0.020 \\
\hline D5 & 0.099 & 0.099 & 0.139 & 0.139 & 0.099 \\
\hline D6 & 0.182 & 0.182 & 0.182 & 0.182 & 0.182 \\
\hline $\mathrm{d}^{*}$ & 0.343 & 0.253 & 0.311 & & \\
\hline $\mathrm{d}^{-}$ & 0.264 & 0.325 & 0.250 & & \\
\hline
\end{tabular}


On the other hand, based on TOPSIS ideal solution of closeness coefficient rank in Table 7 , construction stage (0.563) is high-risk, post construction stage (0.446) the second, and pre-construction stage (0.435) the least.

Table 7. Ranking of Risk Level of Schedule Delay on Construction Process.

\begin{tabular}{ccc}
\hline Rank & Alternatives & Closeness Coefficient \\
\hline 1 & Construction & 0.563 \\
2 & Post construction & 0.446 \\
3 & Pre-construction & 0.435 \\
\hline
\end{tabular}

As a result, the risk of schedule delay at the different lifecycle of construction projects has a difference or the risk impact different either in level or in type. These differences are important to mitigation delay risk in the construction projects of Ethiopia by recognizing the exact influence level of risk at each activity for a better decision. Overall, Figure 2 shows the comparison of the risk of the major schedule delay risk factors, external, resource, responsibility, and contract condition related.

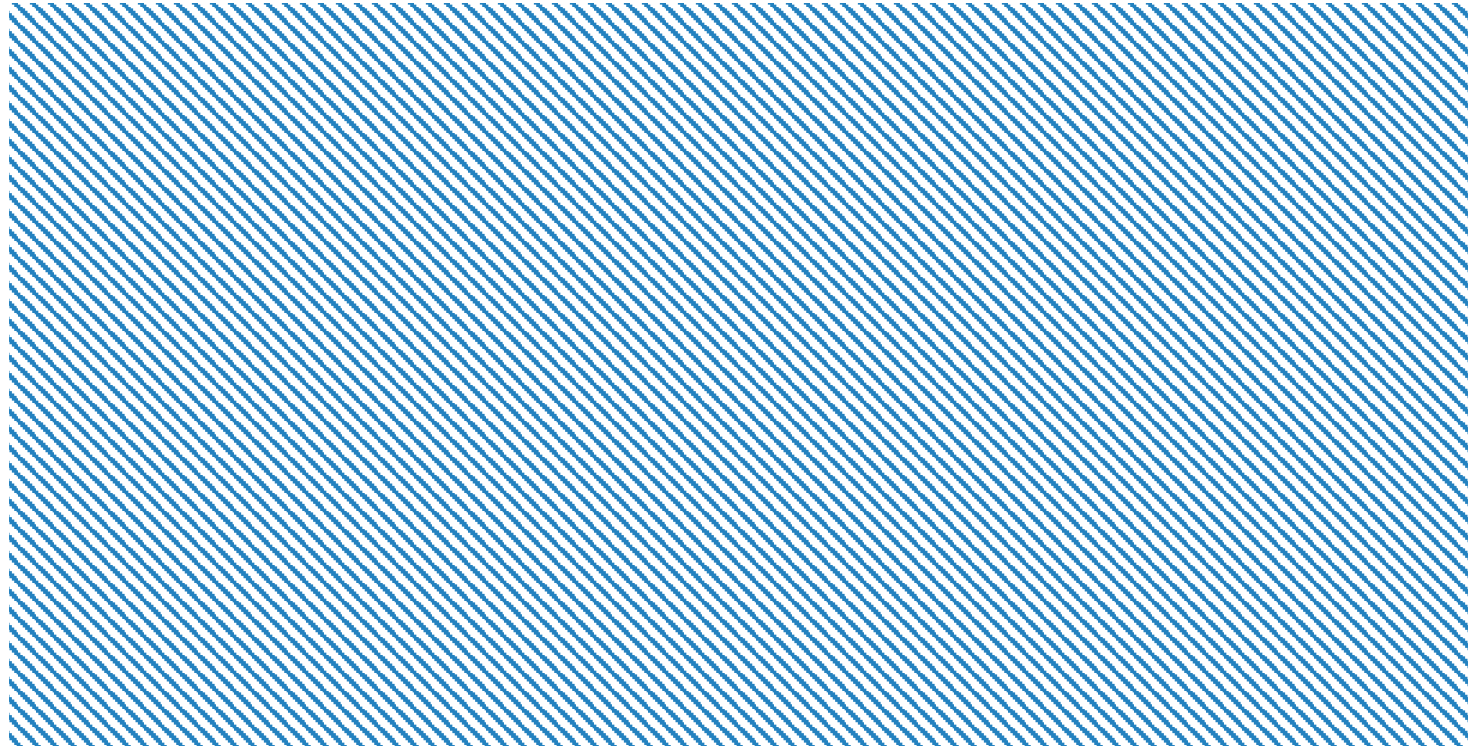

Figure 2. Risk of criteria on construction stage.

The study detects the influence of schedule delay risk in the construction projects of Ethiopia. The construction projects in Ethiopia have faced an average of $38 \%$ schedule delay risk at high and very high-risk level (Table 6). The rank, based on TOPSIS Closeness Coefficient and multi-comprehensive evaluations of risk at high and very high-risk level of alternatives are denoted in Figure 3. 


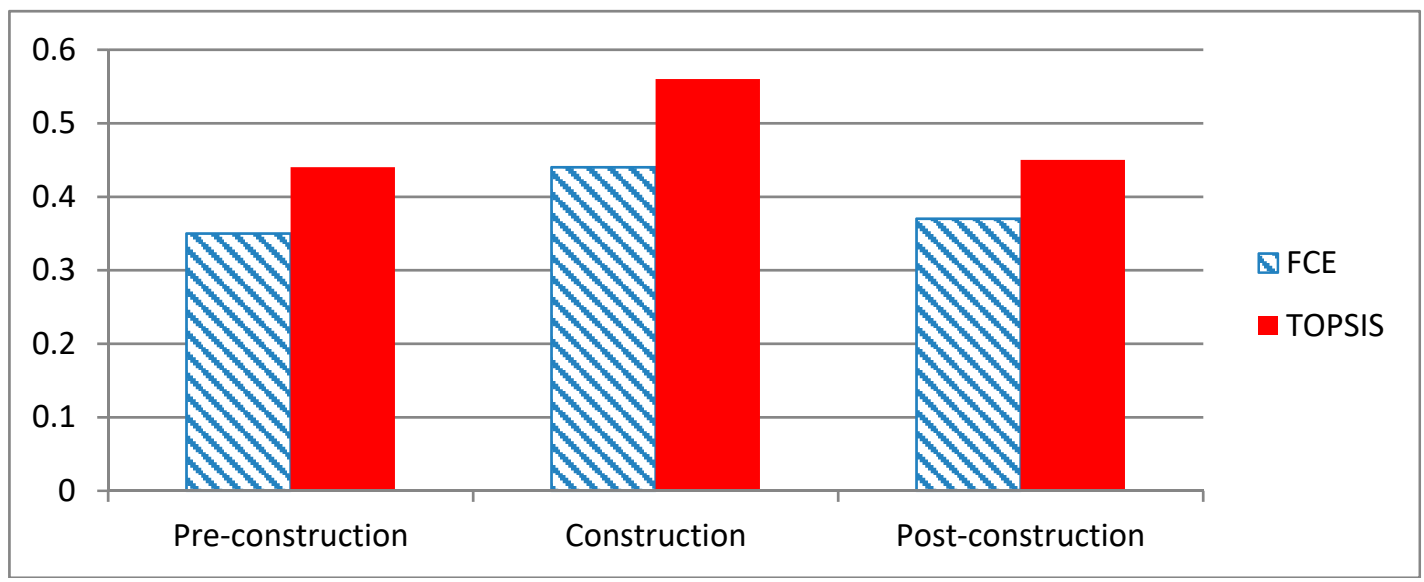

Figure 3. Comparison of risk of schedule delay by FCE and TOPSIS on the construction lifecycle.

\section{Conclusions}

Schedule delay risk was analyzed to provide a decision regarding the typical risk of delay in construction lifecycle to mitigate risk. This was achieved through the application of the hybrid model of FCE and TOPSIS. The application of this combined model can evaluate not only the typical risk of the schedule delay but also reflects the general risk of schedule delay. Based on the empirical study, the results identified that the risk level of the schedule delay varies at the construction projects lifecycle. The comparison on the empirical study shown that the construction stage $(44 \%)$ is high risk, the second high-risk stage is post construction (37\%), and the least risk is pre-construction (35\%). The construction projects in Ethiopian have faced an average of $38 \%$ of schedule delay risk at the high and very high-risk level. This helps the construction managers to identify which schedule delay risk factor is highly influential and which construction lifecycle is highly risky and to make the right decision on how to mitigate the risk. The application of the integrated model of FCE and TOPSIS is a viable tool in delay risk management of construction project. The model can be applied at any time, with different project types by adapting the factors and evaluated weight.

Author Contributions: The author's responsibility and contribution during the study expressed as T.G. had the responsibility and contribution to propose the research and develop a methodology, collected and analyzed data, and obtained results; H.L. assisted and organized the study throughout the research process and provided extensive advice. The authors have carefully read and approved the manuscript.

Funding: “Huazhong University of Science and Technology under the National 12th Five-Year Plan Major Scientific and Technological Issues through grant 2015BAK33B04" funded this research.

Conflicts of Interest: We have no conflict of interest to disclose.

\section{References}

1. Mohammadsoroush, T. Dynamic Risk Analysis of Construction Delays Using Fuzzy-Failure Mode Effects Analysis. Master's Dissertation, University of Nevada, Las Vegas, NV, USA, 2017. Available online: https: / / digitalscholarship.unlv.edu/thesesdissertations/3043 (accessed on 23 December 2018).

2. Zou, P.X.W.; Zhang, G.; Wang, J. Understanding the key risks in construction projects in China. Int. J. Proj. Manag. 2007, 25, 601-614. [CrossRef]

3. Mahamid, I.; Bruland, A.; Dmaidi, N. Causes of Delay in Road Construction Projects. J. Manag. Eng. 2012, 28, 300-310. [CrossRef]

4. Choudhry, R.M.; Aslam, M.A.; Hinze, J.W.; Arain, F.M. Cost and Schedule Risk Analysis of Bridge Construction in Pakistan: Establishing Risk Guidelines. J. Constr. Eng. Manag. 2014, 140. [CrossRef]

5. Szymański, P. Risk management in construction projects. Procedia Eng. 2017, 208, 174-182. [CrossRef]

6. Gonzalez, P.; Gonzalez, V.; Molenaar, K.; Orozco, F. Analysis of Causes of Delay and Time Performance in Construction Projects. J. Constr. Eng. Manag. 2014, 140. [CrossRef] 
7. Han, S.; Love, P.; Peña-Mora, F. A system dynamics model for assessing the impacts of design errors in construction projects. Math. Comput. Model. 2013, 57, 2044-2053. [CrossRef]

8. Faridi, A.S.; El-Sayegh, S.M. Significant factors causing schedule delay in the UAE construction industry. Constr. Manag. Econ. 2006, 24, 1167-1176. [CrossRef]

9. Sambasivan, M.; Soon, Y.W. Causes and effects of delays in Malaysian construction industry. Int. J. Proj. Manag. 2007, 25, 517-526. [CrossRef]

10. Assaf, S.A.; Al-Hejji, S. Causes of schedule delay in large construction projects. Int. J. Proj. Manag. 2006, 24, 349-357. [CrossRef]

11. Ayalew, T.; Dakhli, Z.; Lafhaj, Z. Assessment on Performance and Challenges of Ethiopian Construction Industry. J. Arch. Civ. Eng. 2016, 2, 1-11.

12. Abd El-Razek, M.E.; Bassioni, H.A.; Mobarak, A.M. Causes of Schedule delay in Building Construction Projects in Egypt. J. Constr. Eng. Manag. 2008, 134, 831-841. [CrossRef]

13. Frimpong, Y.; Oluwoye, J.; Crawford, L. Causes of schedule delay and cost overruns in construction of groundwater projects in a developing countries; Ghana as a case study. Int. J. Proj. Manag. 2003, 21, 321-326. [CrossRef]

14. Gunduz, M.; Nielsen, Y.; Ozdemir, M. Quantification of Delay Factors Using the Relative Importance Index Method for Construction Projects in Turkey. J. Manag. Eng. 2013, 29, 133-139. [CrossRef]

15. Larsen, J.K.; Shen, G.Q.; Lindhard, S.M.; Brunoe, T.D. Factors Affecting Schedule Schedule delay, Cost Overrun, and Quality Level in Public Construction Projects. J. Manag. Eng. 2016, 32. [CrossRef]

16. Xu, X.; Wang, J.; Li, C.Z.; Huang, W.; Xia, N. Schedule risk analysis of infrastructure projects: A hybrid dynamic approach. Autom. Constr. 2018, 95, 20-34. [CrossRef]

17. Abd El-Karim, M.S.B.; Mosa El Nawawy, O.A.; Abdel-Alim, A.M. Identification and assessment of risk factors affecting construction projects. HBRC J. 2015, 13, 202-216. [CrossRef]

18. Tavakolan, M.; Etemadinia, H. Fuzzy Weighted Interpretive Structural Modeling: Improved Method for Identification of Risk Interactions in Construction Projects. J. Constr. Eng. Manag. 2017, 143. [CrossRef]

19. Hossen, M.M.; Kang, S.; Kim, J. Construction schedule delay risk assessment by using combined AHP-RII methodology for an international NPP project. Nucl. Eng. Technol. 2015, 47, 362-379. [CrossRef]

20. Attri, R.; Grover, S.; Dev, N.; Kumar, D. Analysis of barriers total productive maintenance (TPM). Int. J. Syst. Assur. Eng. Manag. 2013, 4, 313-326. [CrossRef]

21. Kim, D.Y.; Han, S.H.; Kim, H.; Park, H. Structuring the prediction model of project performance for international construction projects: A comparative analysis. Expert Syst. Appl. 2009, 36 Pt 1, 1961-1971. [CrossRef]

22. Luu, V.T.; Kim, S.-Y.; Tuan, N.V.; Ogunlana, S.O. Quantifying schedule risk in construction projects using Bayesian belief networks. Int. J. Proj. Manag. 2009, 27, 39-50. [CrossRef]

23. Wang, J.; Yuan, H. System Dynamics Approach for Investigating the Risk Effects on Schedule Delay in Infrastructure Projects. J. Manag. Eng. 2017, 33. [CrossRef]

24. Adams, F.K. Risk perception and Bayesian analysis of international construction contract risks: The case of payment delays in a developing economy. Int. J. Proj. Manag. 2008, 26, 138-148. [CrossRef]

25. Eybpoosh, M.; Dikmen, I.; Birgonul, M.T. Identification of Risk Paths in International Construction Projects Using Structural Equation Modeling. J. Constr. Eng. Manag. 2011, 137, 1164-1175. [CrossRef]

26. Wang, W.-C.; Lin, C.-L.; Wang, S.-H.; Liu, J.-J.; Lee, M.-T. Application of importance-satisfaction analysis and influence-relations map to evaluate design delay factors. J. Civ. Eng. Manag. 2014, 20, 497-510. [CrossRef]

27. Boateng, P.; Chen, Z.; Ogunlana, S. A dynamic framework for managing the complexities of risks in megaprojects. Int. J. Technol. Manag. Res. 2016, 5, 1-13.

28. Karim, R.; Karmaker, C. Machine Selection by AHP and TOPSIS Methods. Am. J. Ind. Eng. 2016, 4, 7-13. [CrossRef]

29. Jang, W.; Hong, H.; Baek, S. Optimal Supply Vendor Selection Model for LNG Plant Projects Using Fuzzy-TOPSIS Theory. J. Constr. Eng. Manag. 2017, 33. [CrossRef]

30. El-Sayegh, S.M. Risk assessment and allocation in the UAE construction industry. Int. J. Proj. Manag. 2008, 26, 431-438. [CrossRef]

31. Yoon, Y.; Tamer, Z.; Hastak, M. Protocol to Enhance Profitability by Managing Risks in Construction Projects. J. Manag. Eng. 2015, 31. [CrossRef] 
32. Kuo, Y.-C.; Lu, S.-T. Using fuzzy multiple criteria decision making approach to enhance risk assessment for metropolitan construction projects. Int. J. Proj. Manag. 2013, 31, 602-614. [CrossRef]

33. Dikmen, I.; Birgonul, M.T.; Anac, C.; Tah, J.H.M.; Aouad, G. Learning from risks: A tool for post-project risk assessment. Autom. Constr. 2008, 18, 42-50. [CrossRef]

34. Rao, R.; Zhang, X.; Shi, Z.; Luo, K.; Tan, Z.; Feng, Y. A Systematical Framework of Schedule Risk Management for Power Grid Engineering Projects' Sustainable Development. Sustainability 2014, 6. [CrossRef]

35. Chatterjee, K.; Zavadskas, K.E.; Tamošaitienè, J.; Adhikary, K.; Kar, S. A Hybrid MCDM Technique for Risk Management in Construction Projects. Symmetry 2018, 10. [CrossRef]

36. Nguyen, A.T.; Nguyen, L.D.; Long, L.-H.; Dang, C.N. Quantifying the complexity of transportation projects using the fuzzy analytic hierarchy process. Int. J. Proj. Manag. 2015, 33, 1364-1376. [CrossRef]

37. Lee, M.C. Information security risk analysis method and research trends: AHP and fuzzy comprehensive method. Int. J. Comput. Sci. Inf. Technol. 2014, 6, 29.

(c) 2018 by the authors. Licensee MDPI, Basel, Switzerland. This article is an open access article distributed under the terms and conditions of the Creative Commons Attribution (CC BY) license (http://creativecommons.org/licenses/by/4.0/). 